\title{
Social Housing for Women Heads of Household in Congo Brazzaville
}

\author{
Ndongo Alain Symphorien', Bachynskaya Lyudmila Georgievna² \\ ${ }^{1}$ LMEI/CUSI, Marien N'GOUABI University, Higher National Polytechnic School, Brazzaville, Congo \\ ${ }^{2}$ Kyiv National University of Civil Engineering and Architecture, Kiev, Ukraine \\ Email: asymphoriendongo@gmail.com
}

How to cite this paper: Symphorien, N.A. and Georgievna, B.L. (2019) Social Housing for Women Heads of Household in Congo Brazzaville. Open Journal of Social Sciences, 7, 383-396.

https://doi.org/10.4236/jss.2019.78028

Received: July 31, 2019

Accepted: August 26, 2019

Published: August 29, 2019

Copyright $\odot 2019$ by author(s) and Scientific Research Publishing Inc. This work is licensed under the Creative Commons Attribution International License (CC BY 4.0).

http://creativecommons.org/licenses/by/4.0/

\begin{abstract}
The results of the 1974, 1984 and 2007 general population censuses show a remarkable growth of women and girls compared to men and boys. Among the population are many single women, divorced and widowed, who are heads of their own households. The chronic urban housing crisis in Congo and the lack of a functional principle for the development of collective social housing only surprise Congo's decision-makers and development partners. However, how can vulnerable female-headed households be housed in order to permanently eradicate gender inequality and repair the damage caused to women? This article reviews the status of women and the current urban housing situation from four perspectives, including: household type and size, housing content and surface area per member. Based on a literature review of population survey data, the study proposes three main types of social housing for female-headed households, with areas ranging from $25 \mathrm{~m}^{2}$ to $90 \mathrm{~m}^{2}$. Thus each household member benefits from between $8.50 \mathrm{~m}^{2}$ and $12 \mathrm{~m}^{2}$. The European Union delegation to the Republic of Congo, the creation by the Government of the Congolese Housing Bank $(\mathrm{BCH})$ and the Sino Congolese Bank for Africa (BSCA) are a major asset in the fight against poverty and the improvement of people's living conditions.
\end{abstract}

\section{Keywords}

Household, Family, Female Head of Household, Social Housing, Congo, Housing Area Per Member

\section{Introduction}

The importance of women's role in Congolese society in economic, educational and security matters is well recognized by all and is receiving sustained attention from governments, development partners and civil society. This can be demon- 
strated by the existence of a national framework to combat gender inequalities and the National Committee to Combat Poverty [1]. In Congo, women are led to assume domestic responsibility because they live alone or without an adult man present, or because of a "failing" husband. As shown by the results of the general population and housing census in 2007, there are about 885,160 households, $60.9 \%$ of which live in urban areas and $39.1 \%$ in rural areas. Of which $75.8 \%$ are led by men against $24.2 \%$ by women [1] [2].

Gender inequalities are still widespread in the Republic of Congo, placing women and girls in a less favourable position than men and boys. Women and girls have fewer rights, less information, less access to all kinds of resources and experience more gender-based violence than their male counterparts. Strong patriarchal values and certain traditions place women in a subordinate position as second-class citizens [3]. As a result, female-headed households are generally considered to be part of vulnerable social groups. Yet, there is already a national framework to address gender inequalities, including a national strategy to promote gender equality and a revised family code [4]. However, their implementation remains theoretical.

The gradual increase in the percentage of female-headed households encourages the Government of the Republic and its development partners to study the demography of this group and its socio-economic situation [3]. However, housing laws, regulations and policies are not yet adapted to the needs of female-headed households and housing offers do not meet the specific needs of this group. Single girls who have reached the age of 45 are often embarrassed to continue living with their parents. Also divorced women are usually made available to their parents, or they no longer have housing [5]. As for widows, the situation is often tragic, as they are often expelled by the successor (heir) of the spouse, who has his own home. These cases are very common in urban areas. The right to adequate housing, as a component of the right to a comfortable standard of living, is enshrined in many international human rights' instruments [6] [7].

The objective of this study is to differentiate between the concepts of family and household under Congolese conditions. Specifically, the objective is to identify female-headed households in order to identify principles for designing appropriate social housing.

The data for this study come from documents of the United Nations Development Programme (UNDP), the World Bank, the National Institute of Statistics (NIS) and the Ministry for the Advancement of Women and the Integration of Women in Development [1] [2] [3] [6].

\section{Family and Household Concepts in Congolese Society}

In the literature, the household category is often confused with the family category, although they are closely related. The publication of general population census results suggests an ambiguity between the two concepts. Behind the con- 
cept of "head of household" is still the traditional conception of head of family. In Congolese customs, (Kongo, Mbochis, Téké, etc.) there is a great difference between the two notions [4].

\subsection{The Congolese Family}

According to the law, "the family includes all persons united by marriage or blood relationship, or even by adoption". It is headed by a head of family who is generally male, with authority over all children and descendants up to the 8th degree (generations). Members of the same family may not cohabit because of its size. However, they meet periodically during family councils, dowry celebrations, weddings, funerals and other events [4].

When a child reaches adulthood, he leaves his parents' home to found his own home, he remains a member of the family whose name he bears, but here he becomes head of the household. Thus, several households can no longer live together in the same dwelling. A household is therefore a dwelling and the family is a group of households.

The main tasks of the head of the family are to ensure the empowerment of its members, to organize and preside over family events, in particular the presidents and dowries, palavers, relating to cases of illness, as well as funeral wakes. He is often assisted by the elders (traditional judges). Here it is the man who is the leader, that is, the father or son of his sister (the nephew). Women's power is relegated to their brothers or eldest son [5].

\subsection{The Household}

The household is a collective unit or social group, made up of related or unrelated individuals living under the same roof, who share their resources and expenses. The housing unit is therefore the preferred characteristic to define a household unlike the family, which is defined by kinship ties: household members have a daily life in common (expenses, sharing meals), while family members occasionally meet during family events (weddings, mourning, birth, talks, etc.).

The head of the household is a reference person from whom the other members are identified. This notion implies the existence of a relationship of dependence between the head and his cohabitant. The head of the household is under the authority of a head of the family and can be male or female. Already in the 14th century, the pioneers of the general population censuses carried out an inventory of the number of "fires" throughout the kingdom. The aim was to identify households in order to serve as a basis for tax collection. There is here an idea of a housing household [8] [9] [10].

\section{Female-Headed Households}

The importance of female heads of households at the international level has been revealed by censuses and household studies conducted in Europe and the United 
States of America. This reflection begins at the African level with studies by the French Centre on Population (CEPED), as well as those of specialists such as: $\mathrm{M}$. Buvinic, N. Youssef, B. Von Elm, C. B. Hetler, E. Cecelski, K. Sissoko, Reem Hamad, Ahmed S. Abd Elrahman, I. Ayat [6] [8] [9] [11] [12] [13].

At the national level, the National Institute of Statistics (INS), during the last general population and housing census, studied the characteristics of ordinary households as well as those of heads of households. These studies highlight the exception that makes women heads of households in Congo [1] [2]. Indeed, women heads of household are characterized by authority, decision-making power, economic contribution and mode of residence.

\subsection{Women's Access to the Status of Head of Household}

In Congo, even in urban areas, women participate in the economic maintenance of the family in general and the household in particular through their activities (agricultural, craft, commercial, administrative, etc.). This contribution is recognized at all levels. It is in this code that women exercise their authority in the household, especially in the education of children [12] [13]. The woman becomes the head of the household when the husband fails to act. Thus, celibacy, divorce and widowhood are the main causes of women's access to the status of head of household. In addition, there may be 2 nd, 3rd or 4 th wives in polygamous unions.

The general population and housing census reveal that female heads of household are mainly single $(47.7 \%)$; widows $(23.1 \%)$ and divorced $(14.1 \%)$ (Table 1) [1] [2].

\subsection{Economic Activity of Heads of Households}

In RGPH-07, the economic activities of heads of households were grouped into 8 groups. Women heads of households are represented in all categories (scientific,

Table 1. Percentage distribution of heads of household by marital status by sex in urban areas.

\begin{tabular}{ccc}
\hline Marital status & \multicolumn{2}{c}{ Sex } \\
\cline { 2 - 3 } Single people & Male \% & Female \\
\hline Married Polygamous 2 spouses & 25.2 & 2.5 \\
Married Polygamous 3 spouses & 1.9 & 0.2 \\
Married Polygamous 4 spouses & 0.1 & 0.1 \\
Divorced & 0.1 & 14.1 \\
Widow & 1.7 & 23.1 \\
Married monogamous & 1.2 & 12.3 \\
TOTAL & 69.8 & 100 \\
\hline
\end{tabular}

Source: RGPH-07. 
technical, professional, self-employed, administrative and managerial staff, commercial and sales staff, service workers, farmers, herders, labourers and labourers, etc.). In addition, $13.90 \%$ of women hold management positions in the public service [1] [2].

\subsection{Type and Size of Female-Headed Households in Urban Areas}

According to the 1984 General Population and Housing Census, there were 49.9\% of urban households in 1984 and $60.9 \%$ in 2007 [1] [2].

According to Table 2, regardless of the place of residence, the size of Congolese households varies between 1 and 15 people. Households with 1 to 6 persons are the most likely to respond: $68.8 \%$ in 1984 and $82.4 \%$ in 2007 . On the other hand, households with 7 to 15 or more people are less numerous: $31.2 \%$ in 1984 compared to $17.6 \%$ in 2007 . Rates of heads of households increase with age regardless of geographical, educational or gender background. Therefore, the study recommends the sizes of female-headed households, those that range in size from 1 to 6 people.

\subsection{Types of Households}

Examination of the table below reveals that children, brothers (or sisters), nephews (or nieces), grandchildren (and/or daughters), great-grandchildren

Table 2. Distribution in \% of households.

\begin{tabular}{|c|c|c|}
\hline \multirow{2}{*}{$\begin{array}{c}\text { Household size } \\
\text { (number of people) }\end{array}$} & \multicolumn{2}{|c|}{ Census (In \%) } \\
\hline & 1984 & 2007 \\
\hline 1 & 14.5 & 17.8 \\
\hline 2 & 13.2 & 14.4 \\
\hline 3 & 11.7 & 15.4 \\
\hline 4 & 10.9 & 14.2 \\
\hline 5 & 9.7 & 11.7 \\
\hline 6 & 8.8 & 8.9 \\
\hline 7 & 7.6 & 6.2 \\
\hline 8 & 6.2 & 4.1 \\
\hline 9 & 4.9 & 2.6 \\
\hline 10 & 4.3 & 2.2 \\
\hline 11 & 2.1 & 0.7 \\
\hline 12 & 1.9 & 0.5 \\
\hline 13 & 1.8 & 0.4 \\
\hline 14 & 1.7 & 0.3 \\
\hline 15 and more & 0.7 & 0.6 \\
\hline
\end{tabular}

Source: RGPH-07. 
(and/or daughters) are the dominant members of households in Congo [1] [2] Depending on the generosity and other qualities of the head of household, there may be the presence of the mother (or father); the aunt (or uncle) of the head of household and sometimes unrelated persons.

In view of the above, Congolese households, whether headed by a man or a woman, most often house children, brothers (or sisters), nephews (or nieces), grandsons (and/or daughters), great-grandchildren (and/or daughters) and sometimes ascendants or unrelated persons (Table 3).

As a result, the types of female-headed households are as follows:

Type 1: Head of household living alone,

Type 2: Head of household living with direct and indirect descendants (children, nephews, nieces, grandchildren, great-grandchildren, great-grandchildren),

Type 3: Head of household living with relatives in the ascending line (father/mother, uncle/aunt).

Type 4: Head of household living with collateral (brother/sister, cousin/ cousin),

Type 5: Head of household living with unrelated persons.

Other combinations are possible.

Most heads of households are 2nd, 3rd, 4th women in polygamous unions, singles, widows and divorced women. They are generally women aged 30 and over, who house other members aged 0 to 25 except ascendants (father/mother; uncle/aunt). The exercise of the function of head of household is therefore not exclusive to men. Thus, strong measures must be taken to ensure adequate housing for this social category.

Table 3. Weight of dependents (\%) not related to the head of household by gender of the head of household.

\begin{tabular}{cccc}
\hline Relationship to the head of household & All together & Male & Female \\
\hline Husband/Wife & 0.59 & 0.76 & 0.01 \\
Children & 1.72 & 1.86 & 1.30 \\
Father/Mother & 0.02 & 0.02 & 0.03 \\
Brother/Sister & 0.13 & 0.12 & 0.17 \\
Cousin/Cousin & 0.03 & 0.03 & 0.04 \\
Uncle/Aunt & 0.01 & 0.01 & 0.01 \\
Nephew/Niece & 0.20 & 0.19 & 0.23 \\
Grandson (daughter) Ar. PF & 0.27 & 0.18 & 0.59 \\
Other relative & 0.04 & 0.04 & 0.06 \\
Parent in law & 0.10 & 0.11 & 0.06 \\
Unrelated to each other & 0.04 & 0.04 & 0.03
\end{tabular}

Source: RGPH-07. 


\section{Current Housing Situation of Female-Headed Households}

After demonstrating the existence of female-headed households, we will now review the typological characteristics of the current housing stock. According to the results of the 2007 general population and housing census and the results of the Congolese household survey for poverty assessment (ECOM2005), the housing stock is largely dominated by individual houses $(64.4 \%)$, especially in urban areas. Of which 59\% of households own their own homes, while $37.2 \%$ are tenants. These results indicate that since Congo's independence, construction and real estate development companies, which in turn had been given the task of implementing the housing construction policy by different Governments, have never fulfilled their tasks. The 2007 census counted $2.6 \%$ of households living in modern dwellings [1] [2]. Thus about $97 \%$ of the urbanized territory is made up of slums.

The characteristics of the household and its head influence the type of housing.

Table 4 shows that the rate of single women increased from $15.3 \%$ in 1974 to $30.6 \%$ in 1984 and $42.4 \%$ in 2007. Divorced and widowed women represented $7 \%$ and $10.2 \%$ respectively in $1974 ; 6.1 \%$ and $8.3 \%$ in 1984 , also $3.9 \%$ and $7.5 \%$ in 2007. It is this portion of the population that represents women heads of household in Congo, 32.5\% in 1974; $45 \%$ in 1984 and $53.8 \%$ in 2007.

UN publications-Habitat refers to the slum phenomenon as a manifestation of a poorly planned and managed urban sector. It is also the dysfunction of the housing sector, which does not take into account the presence and needs of all the living strata of the nation [14]. Well-designed housing, which takes into account the environmental, demographic, social, cultural and economic context of communities, is one of the factors that influence the daily lives of household members, their sustenance, safety and well-being.

\section{Results and Discussions}

Analysis of the spaces occupied by female-headed households shows that gender inequality remains a housing concern in Congo. According to surveys conducted by independent experts, statistics on housing typology show that $34.78 \%$ of

Table 4. Evolution of the matrimonial structure from 1974 to 2007.

\begin{tabular}{ccccccc}
\hline \multirow{2}{*}{ Matrimonial structure } & \multicolumn{2}{c}{1974} & \multicolumn{2}{c}{1984} & \multicolumn{2}{c}{2007} \\
\cline { 2 - 7 } & Male & Female & Male & Female & Male & Female \\
\hline Single people & 36.2 & 15.3 & 46.6 & 30.6 & 53.2 & 42.4 \\
Married people & 59.8 & 67.5 & 51.0 & 55.8 & 44.6 & 46.3 \\
Divorced & 2.6 & 7.0 & 2.1 & 6.1 & 1.2 & 3.9 \\
Widowers/Widows & 1.4 & 10.2 & 0.9 & 8.3 & 0.9 & 7.5 \\
Total & 100 & 100 & 100 & 100 & 100 & 100
\end{tabular}

Source: RGPH-07. 
housing is made of precarious materials and $12.82 \%$ of recycled materials (waste boards and sheet metal) reflect poverty [3]. These dwellings have rooms of less than $8 \mathrm{~m}^{2}$ and a height of less than $2.50 \mathrm{~m}$ : it is the precarious housing that does not take into account: the bathroom, toilets, kitchen, access to drinking water and electricity, etc. It is under these conditions that about $60 \%$ of households headed by women are housed, especially those formed after divorce or widowhood.

\subsection{The Characteristics of New Types of Housing for Female-Headed Households.}

The various studies show that housing must include functional areas for domestic activities [15]. And take into account the living space for each household member. Thus, this study proposes three types of housing for female-headed households, including:

Type 1: Bedroom, veranda, shower room, kitchen with dining areas.

This accommodation is intended for a woman living alone or with 1 or 2 children under 15 years of age. The surface area of the dwelling can vary between 25 and $40 \mathrm{~m}^{2}$, i.e. between $8.30 \mathrm{~m}^{2}$ and $11.60 \mathrm{~m}^{2}$ per person. Figure 1 illustrates a typical housing model.

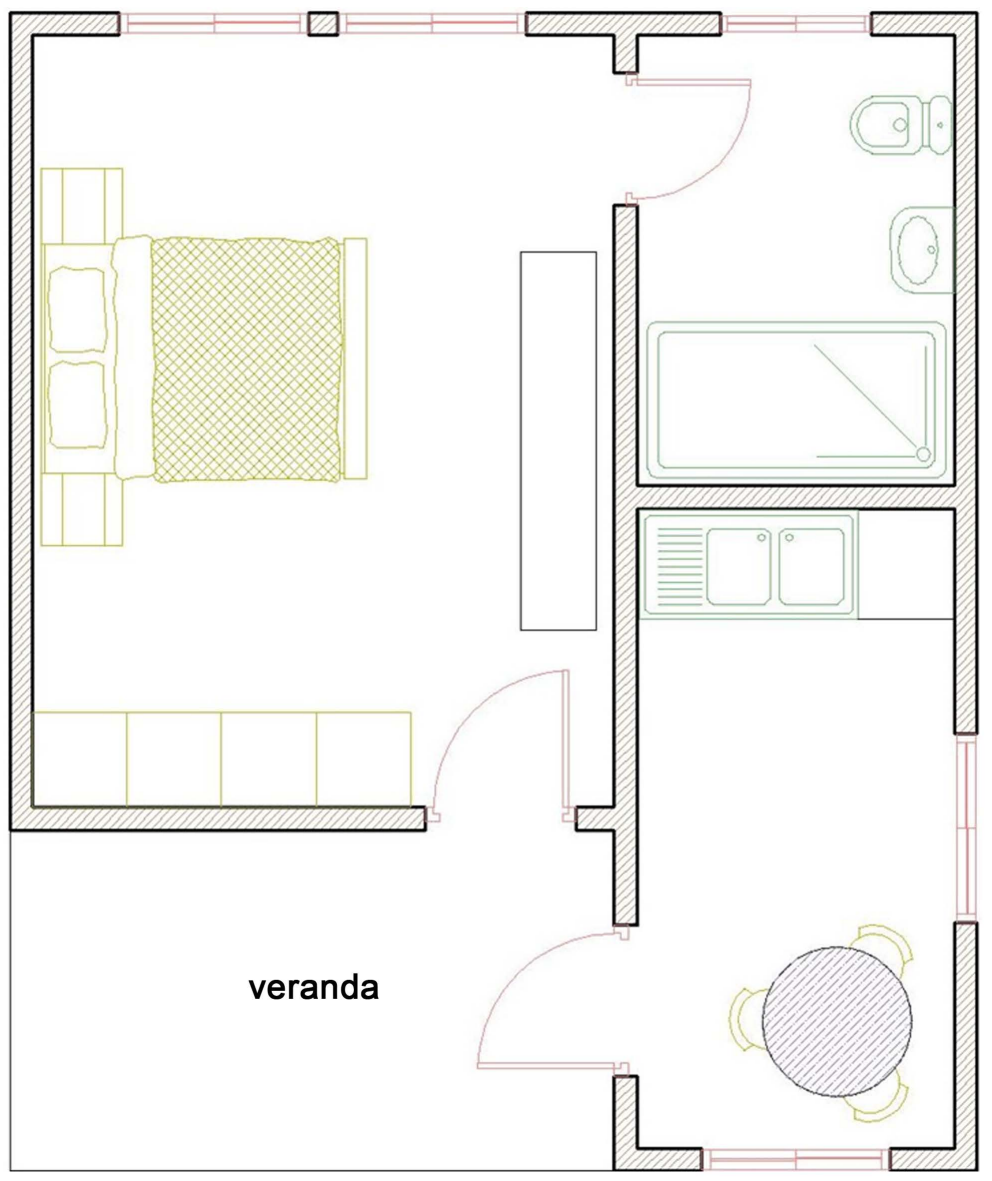

Figure 1. Type 1 dwelling unit. 
Type 2: Two bedrooms, veranda, hallway, shower room, kitchen with dining area (Figure 2).

This type of housing can accommodate compound households:

- A woman head of household, her mother and/or father or sister; 1 to 2 children under 15 years of age.

- A woman head of household, 2 to 5 children aged 0 to 30 years etc.

This accommodation can accommodate between 4 to 6 people with a surface area that varies between 50 and $65 \mathrm{~m}^{2}$.

Type 3: Head of household room with shower room, two bedrooms, two verandas, a shower room, a kitchen with dining area (Figure 3).

This accommodation can accommodate between 6 to 10 people and its surface area can vary from 70 to $90 \mathrm{~m}^{2}$.

The principles of layout of the three types of housing are shown in the Figure 3.

The three standard housing proposals are characterized by a surface area per household member that varies between $8.50 \mathrm{~m}^{2}$ and $12 \mathrm{~m}^{2}$, and a minimum ceiling height of $2.80 \mathrm{~m}$ that can provide natural lighting and ventilation for rooms [15]. In addition, the dwelling must have a sanitary installation and access to drinking water with sufficient pressure; an electricity installation with access to the urban network.

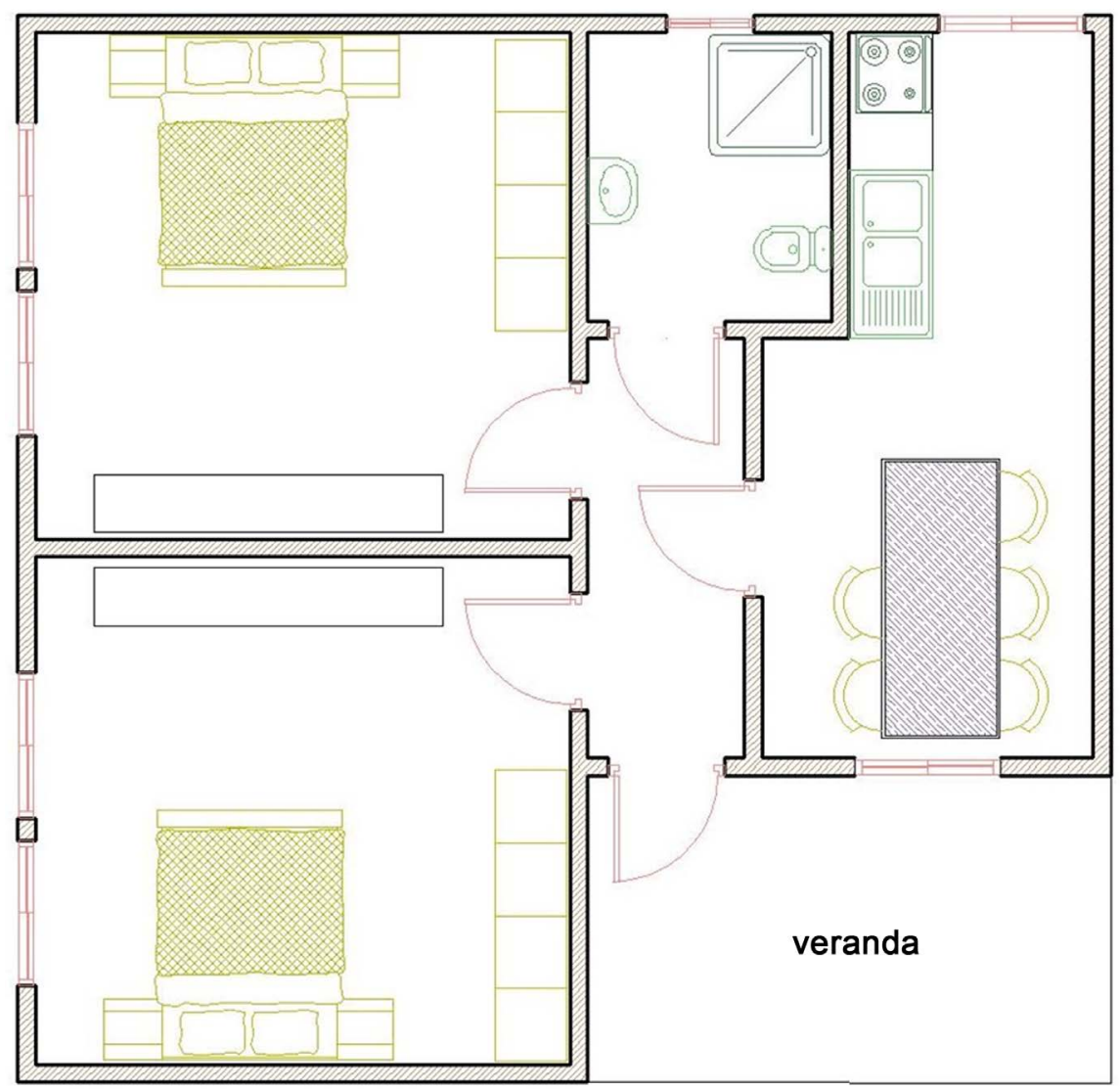

Figure 2. Type 2 dwelling unit. 


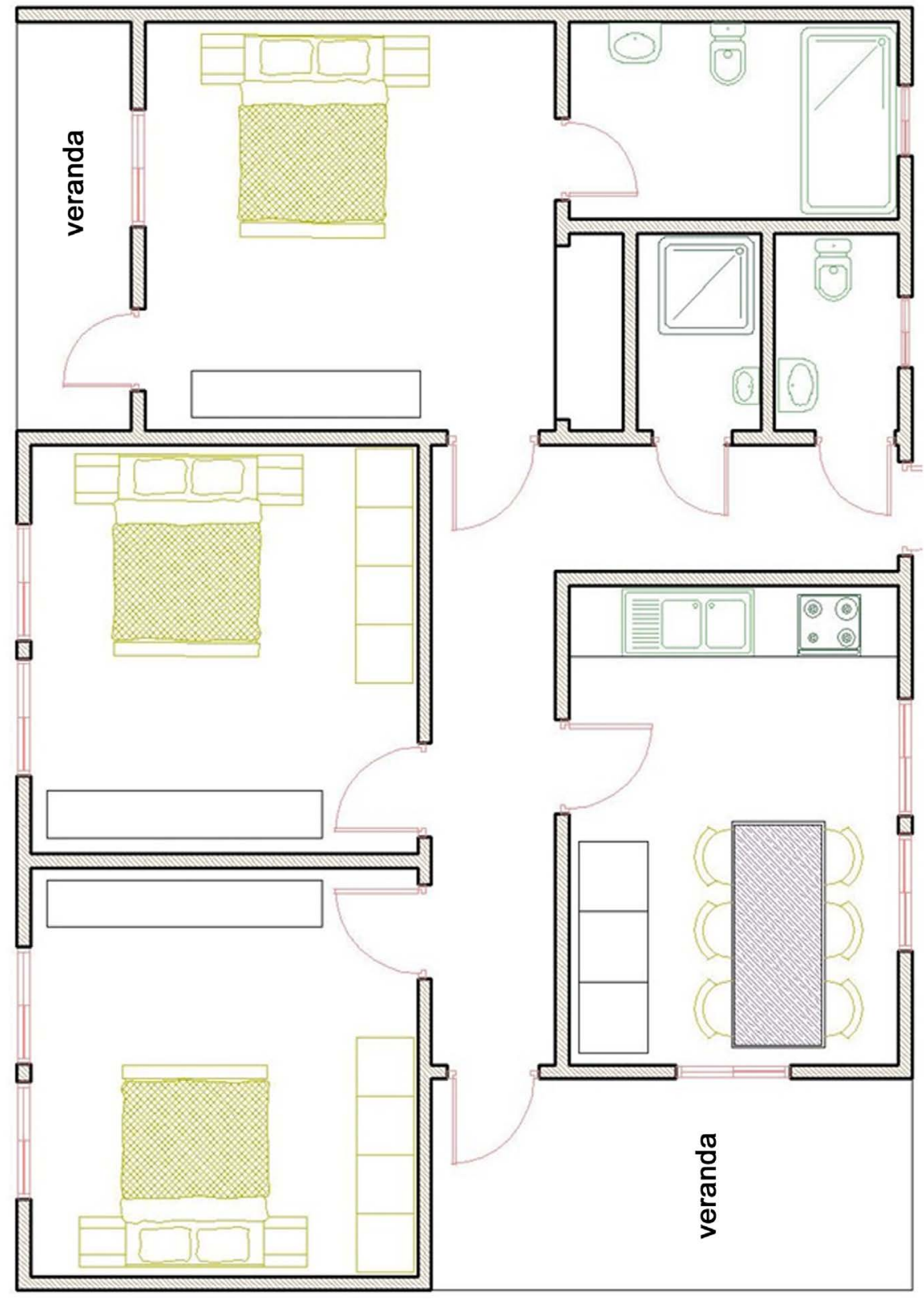

Figure 3. Type 3 dwelling unit.

In view of the above, the household members have the veranda and the kitchen as places of exchange. These functional principles of urban housing design for female-headed households can certainly contribute to women's development. These new types of housing will have a positive impact on:

- The safety of women (single, widowed, divorced), their children and other members;

- The education of children;

- The health of household members;

- The empowerment of Congolese women, who will be able to fully participate in the revival of economic activity in our country. 


\subsection{Suggestion to Improve the Housing Conditions of Female-Headed Households}

At the current stage of seeking social cohesion and economic recovery, concrete measures should be implemented to improve the housing conditions of female-headed households. A policy of intercession of girls in active and social life should be put in place to eradicate the current frustrations in Congolese society. A girl who has reached the age of $25(\mathrm{BAC}+5)$, and is not in a recognized union, should not suffer from any sprain, but should be proud and ready to detach herself from her parents to form her own home, which she will head [16] [17].

In the event of widowhood or divorce, accompanying measures can be taken to avoid turmoil and tensions within the family. Divorce and death are part of our daily lives. In Congo there are many cases where the education of children and their future are mortgaged because of the lack of housing for the woman, who is generally in charge of the children after divorce or widowhood.

Within the urban housing stock, a new type of housing must be provided for female-headed households, which is called upon in special circumstances to ensure the security of children's future.

In addition, a housing security system must be put in place at all levels to help women heads of household to easily obtain housing in urban areas.

The results of this study can be used by housing developers (public or private) in the construction of low-cost housing, in improving the conditions of the existing housing stock. These types of housing will motivate women heads of household to work harder to secure adequate housing without waiting for marriage, which is the only way to separate themselves from their parents.

Thus, free and fictitious unions will no longer have any value in our society, because Congolese women will regain their dignity and efficiency. As a result, she will feel safe and comfortable in this new type of urban housing.

\subsection{Financing of Adequate Social Housing for Female-Headed Households}

Housing is one of the essential social conditions that determine the quality of life and well-being of people and places. Therefore, particular attention should be paid to the financing and allocation mechanism for social housing in general and women's housing in particular.

The cost of construction mainly includes land costs, construction materials, the operation of machinery and instruments, as well as labour related to the various studies and implementation of the works.

The experience of recent years in carrying out the work in the period 2010 to 2016 shows that for the medium-rated building, the cost per square metre excluding land varies between 400,000 FCFA (about $\$ 700$ USD) and 600,000 FCFA (about \$1000 USD).

Thus the $25 \mathrm{~m}^{2}$ housing proposed here will cost 12,500,000 FCFA $(21,250$ USD); the $50 \mathrm{~m}^{2}$ housing will cost 25,000,000 FCFA $(42,500 \$)$ and the $90 \mathrm{~m}^{2}$ housing will cost 45,000,000 FCFA (76,000\$) (Table 5). 
Table 5. Different social housing costs excluding land prices.

\begin{tabular}{cccc}
\hline Type of social housing & Area in $\mathbf{~}^{2}$ & Price per $\mathbf{~ m}^{2}$ Francs CFA & Total price Francs CFA \\
\hline Housing type 1 & 25 & $500000(850 \$)$ & $12,500,000(21,250 \$)$ \\
Housing type 2 & 40 & $500000(850 \$)$ & $20,000,000(34,000 \$)$ \\
Housing type 3 & 50 & & $25,000,000(42,500 \$)$ \\
& 65 & $500000(850 \$)$ & $32,500,000(55,250 \$)$ \\
& 90 & & $45,000,000(59,500 \$)$ \\
\hline
\end{tabular}

Source: proposal of the author.

The European Union delegation in the Republic of Congo is the largest donor in Congo, managing a portfolio of 226 million euros. It uses two instruments in its programme, namely the European Development Fund (EDF) and the instrument to support civil society organisations in various fields [14]. In addition, in November 2007, the Government of the Republic created the Congolese Housing Bank $(\mathrm{BCH})$ to carry out all banking operations aimed at contributing to the implementation and development of housing policy [3]. Thus, the setting up of operations to revitalize the urban fabric by building social housing becomes a reality. The state, in partnership with landowners, can provide the necessary space for the project. In addition, it can requalify certain land abandoned by state companies as bankrupt for the construction of social housing, so that this study can serve as a basis for the development of urban social housing programs in Congo.

\section{Conclusions}

Celibacy, divorce and widowhood are at the origin of the creation of households, whose heads are inevitably women. The education of children and the care of the elderly (senior citizens) are generally provided by women, who have adequate housing.

Currently, the housing problem is one of the factors affecting the education and empowerment of children and women as well as their participation in the economic recovery.

This work reviews the current urban housing situation of female-headed households in four (04) aspects, including: housing choice according to household size.

The research explores the fact that precarious housing in the slum is a particularly compromising solution for female-headed households because it is unhealthy and unworthy.

Social housing in female-headed households can have an area of between 8.50 and $12 \mathrm{~m}^{2}$ by persons, including the bathroom, kitchen, and verandas. That is 25 $\mathrm{m}^{2}$ to $95 \mathrm{~m}^{2}$. By applying the costs in $\mathrm{m}^{2}$ of the current construction $(300,000-$ 500,000 CFA francs) per $\mathrm{m}^{2}$. 
Thus the cost of social housing for female-headed households in urban areas in Congo can be estimated at between 12,000,000,000 FCFA and 47,500,000 FCFA $(\$ 20,000 \$ 80,000)$.

The government of the Republic and its development partners (World Bank, AfDB) can subvert women to $50 \%$ of these dwellings that will go to the woman head of household at a cost of 16,250,000 (about 10,000\$) and 23,750,000 FCFA $(40,000 \$)$.

\section{Conflicts of Interest}

The authors declare no conflicts of interest regarding the publication of this paper.

\section{References}

[1] Institut National de la Statistique (INS) (2012) Recensement général de la population et de l'habitation. Volume 3 dynamique de la population. $87 \mathrm{p}$.

[2] Institut National de la Statistique (INS) (2012) Recensement et le développement (CEPED)-Recensement général de la population et de l'habitation. Volume 5 ménages et habitations. $67 \mathrm{p}$.

[3] Nilson, M. (2017) Profil genre République du Congo (traduit en français par July BashirHanil): Analyse de la situation des filles et des femmes. The European Union's Program for the Republic of Congo. $80 \mathrm{p}$.

[4] Loi $\mathrm{N}^{\circ} 073 / 84 \mathrm{du}$ 17/10/1984 portant code de la famille. $124 \mathrm{p}$.

[5] Balandier, G. (1950) Le problème de la dot et l'organisation familiale, office de la recherche Scientifique d'outremer, côte de classement $\mathrm{N}^{\circ} 567$.

[6] Centre Français sur la population et le Développement (CEPED) (1994) La démographie dans 30 Etats d'Afrique et de l'océan indien, Paris.

[7] Lloyd, C.B. and Brandon, A.J. (1991) Women's Roles in Maintaining Households: Poverty and Gender Inequality in Ghana. The Population Council \& International Center for Research on Women, New York. En français (le rôle des femmes dans le maintien des ménages: Pauvreté et inégalité entre les sexes au Ghana).

[8] Buvinic, M., Youssef, N. and Von Elm, B. (1978) Female Headed of Household: The Ignored Factor in Development Planning. International Center for Research on Women, Vol. 1, No. 2, Washington DC.

[9] Youssef, N. and Hetler, C.B. (1983) Establishing the Economic Condition of Woman-Headed Households in the Word: A New Approach. In: Buvinic, Lycette, M.A. and Greevy, M.C., Eds., Women and Poverty in the Third World, Johns Hopkins University Press, Baltimore, 216-243.

[10] Sissoko, K. (1993) Rôle socioéconomique des femmes dans les unités de production rurales en zone semi-aride de Banama (mali) in séries Notes et travaux No. 8. Centre Sahel de l'Université Laval, Quebec.

[11] Cecelski, E. (1993) l'énergie et le travail des femmes en milieu rural: La crise, les réactions et les solutions. Revue internationale du travail, Vol. 128, Nº 8, Québec centre sahel de l'Université Laval.

[12] Jacobson, J. (1993) Women's Health: The Price of Poverty. In: Koblinsky, M., Timyan, J. and Gay, J., Eds., The Health of Women, a Global Perspective, Westview Press, Boulder, San Francisco, \& Oxford, 3-31. 
[13] Thibaut de saint pol, Aurelie Deney et Olivier MONSO (2004) Ménage et chef de ménage: Deux notions bien ancrées.

https://www.cairn.info/revue-travail-genre-et-sociétes-2004-1-page-63.htm

[14] https://fr.unhabitat.org/urban-themes/logement-et-amelioration-des-bidonvilles

[15] Ndongo, A.S. (1999) Principes fonctionnels d'aménagement pour la configuration des appartements urbains dans les immeubles d'habitation au Congo. Thèse de doctorat $\mathrm{PhD}$, Kiev, $187 \mathrm{p}$.

[16] Oppong, C. and Abu, K. (1987) Seven Roles of Women: Impact of Education, Migration and Employment on Ghanaian Mothers. Work and Development Series No. 13, ILO, Geneva.

[17] Bachynskaya, L.G. (2004) Housing Architecture: Problems of Theory and Practice of Structure Formation: Monograph/Lyudmila Bachynska. University of Building and Architecture, Kiev, 408 p. 